\title{
Challenges for Social Studies Education in Meeting the Millennium Development Goals (MDGS) in Nigeria
}

\author{
Ogunfunmilakin Ifedayo
}

Department of Social Science Education, Adekunle Ajasin University Akungba - Akoko

Doi:10.5901/ajis.2015.v4n1p327

\begin{abstract}
Poverty, a social scourge that every developing nation is struggling to banish. Nearly all the third world nations are still growing under its evil effects. The developed nations are equally looking for a ways out, for the developing nation. One of the way out of these problem is the introduction and embracement of Millennium development goal which was strategically designed to reduce the scourge of poverty and to ensure that poverty becomes a thing of the past in our society. And how education can be used as a tool for national development. This paper also looked at the role of social studies towards the realization of the Millennium development goal and also suggested what can be done to enhance its realization in the third world nations.
\end{abstract}

Keywords: Education, Challenges, Millennium, Development, Goal.

\section{Introduction}

The 1992 Earth summit in Rio de Jeneiro issued the famous agenda 21 (for the 21 $11^{\text {st }}$ century) which provided the main framework for international understanding and Cooperation on the issues of sustainable development. Notably, agenda 21 which identified means of combating poverty as a basic prerequisite for ensuring sustainability be it social, economic and environmental issues The need to combat poverty as social issues was stressed and the key component to move the society forward through sustainable development programmes was equally emphasized.

The term Millennium development goal is a global phenomenon which many nations most especially the developing countries strive to attain. It is a stage of near perfection, and attainment of desired goals. At the millennium summits, the United Nation re-affirmed its commitment to work toward a world in which eliminating poverty and sustaining development would have the highest priority. The millennium development goals which grew out of the world conferences organized by the United Nations in the past decade have been commonly accepted as a framework for measuring developmental progress. The goals focus on the efforts of the world community in achieving significant measurable improvement in peoples' lives. They established yardsticks for measuring results, not just for developing countries but for developed countries that will fund development progress and for the multilateral institutions that help countries to implement such programmes.

Ajibola (2008) and Scoullos (2004) see development as a multi-dimensional process involving the re-organization and re-orientation of the entire economic and social system. They stressed further that it is a process that involves major changes and total transformation in social structure, popular attitudes and national institutions, as well as acceleration of economic growth, the reduction of inequality and the total eradication of absolute poverty. There is no society that is static, and in view of the development we must be geared towards a state of economic liberation, social re-engineering and political stability.

Orungbemi (2010), Medunoye (2008) also saw development of man in the unfolding and full realization of his creative potential, which enabling him to improve his material conditions of living through the use of resources available to him. The human capacity to build to decide what to accomplish in order to live successfully is an ultimate task in achieving the millennium development goals. The determination in achieving this task is purely on discipline, seriousness and focus that give the direction in achieving the task. Cletus (2011) notes that success in achieving this noble goal will depend mostly on the partnership between the government of developed and developing countries while the attainment will also require good will and active participation on the part of the private sector and non governmental organization.

UNDP (2007) sees development as a means of change and total transformation from one stage to another. It believes that planning and action are the ultimate things before development can take place. It therefore sees development as a planned activity which aims at speeding up the process of change which is already going on towards an identified goal. It is a way of mobilizing human and material into an action, that will lead to change or that will 
transform the lives of people positively and will therefore enable the people to realize the need to improve its performance and increase the standard of living of people around them.

However, the millennium development goals were specifically designed to assist the developing nations, which is characterized by different social and economic vices, such as abject poverty, unemployment, insufficient government services, poor quality of life, poor communication system, high level of illiteracy, low per-capital income. Despite the abundant human and natural resources in Nigeria there is prevailing poverty. Only few people are living in luxury while the majority of the citizens living below poverty level. Most of the developing world have the natural resources which are exported at a cheaper rate to the developed countries while they import some materials from the developed nations at an exorbitant rate, the third world countries are been characterized with technological backwardness, rapidly growing population, political instability, relies much on imported materials and widespread, illiteracy.

There are parameter or yard sticks that people usually use to determine whether a country is poor or rich, well fed or not, literate or illiterate, lively or not, good or bad, happy or miserable. The developing nations are at the mercy of the developed countries, they live under poor condition, their economic situation is terrible and nothing to write home about. With this type of situation the developed nations have no option at the level than to intervene and assist the developing nations. As the developing nations were helpless, they see the way out as the best option by tightening their apron spring to the developed nations, and when the developed nations see the consequences ahead, they also design the conditions for liberations for the developing nations through the millennium development goals. They see this as a means of attaining economic and social transformation for the developing nations from deplorable conditions. Nigeria as a typical example of developing nation with large quantity of crude oil, while United States of America (USA) is the largest consumer of Nigeria oil, with the available crude oil in Nigeria, there are series of problems facing Nigeria such as problem of employment; in a bid to search for job, most of the youths have migrate to other countries in an attempt to secure job, political instability, conflicts among the oil producing states, insecurity, proliferation of arms all efforts to salvage these situation was prove abortive as individuals or countries no longer trust one another and this equally alert the international community to spend fortunes in peace keeping operation the developing nations.

At the millennium summit in September 2002, the United Nation re-affirmed its commitment to working toward a world in which eliminating poverty and sustaining development would have the highest priority. The United Nations is resolute in seeing that these problems ravaging the developing nations is addressed once and for all and become a thing of the past, they declared that "we will spare no effort to free our fellow men, women, brothers, sisters and children from abject and dehumanizing conditions of extreme poverty, to which not less than a billion of them are currently subjected:.

Bucknal (2001) stressed that there are eight major Millennium Development Goals, seven of which formulate far reaching improvement, followed by concrete targets to be achieved by 2015. The Millennium Development Goals which can be tagged as the eight points Agenda are listed below:

i. Eradication of extreme poverty and hunger

ii. Achieve Universal Basic Education

iii. Promotion of gender equity and empowerment of women

iv. Reduce child mortality

v. Improvement in maternal health

vi. Combat HIVIAIDS, malaria and other related diseases.

vii. Assurance of environmental sustainability and

viii. Development of a global partnership for development.

Moreover, the millennium development goals range from eradicating poverty to the halting the spread of HIVIAIDS and providing universal basic education to ensure environmental sustainability before 2015 . Also the millennium development goal (MDGS) have unprecedented political backing from the industrialized nations, never before concrete goals have been formally endorsed by rich and poor countries, and never before have the international community come together behind the same developmental agenda.

It is obvious that many of the poorest countries will need additional assistance form the developed countries and the poor countries must look towards the rich countries for necessary assistance and also allowing free exchange of goods and services. However, a development path is sustainable only if it ensures that the stock of all capital assets remains constant and increase overtime. These assets include manufactured capital. (Such as machine and roads). Human capital (such as relationship and institutions) and environmental capital (forest and coral reefs). The environment matters not just because of its effects on the non-economic welfare but because of its impact on production over long term. 


\section{Nigeria and the Millennium Development Goals (MDGS)}

The declaration was made by United Nation (UN) in the year 2000 has created faces and direction in addressing some of the problems facing the developing nations including Nigeria. In achieving these goals within a stipulated time Nigeria must brace up to partner with the developed countries of the world and adopt specific target for poverty reduction and other social and economic vices before 2015.

The Millennium Development Goals (MDGs) is an opportunity and challenges for developing countries like our nation Nigeria. The greatest challenge facing Nigeria is how to meet the Millennium Development Goals. Corruption, poverty, infant mortality, disease, and illiteracy these social vices have remained as major problem of retardation in most of the developing nations. The private sector is weak, external debt remains un-sustainable while social lives generally point to low levels of human development. Insecurity generally has stored the foreign investors while life remains miserable for the people in the developing nations. With the current populations of Nigeria and their abundant resources 75 percentage of their citizen live below the poverty line. In fact, the country Nigeria according to UN rating of 1999 was rated as the $13^{\text {th }}$ poorest nation in the world. The poor state of Nigeria is said to be emanating from bad leadership, economic mismanagement insecurity, ethnic conflict, poor social infrastructure, corruption and other vices.

For developing nations to overcome these problems and to realize the Millennium Development Goals, education become a veritable tool for achieving these noble objectives. Bamisaye (1998) Moreno (2006) asserts that education remains the authentic way to unlock the gate of poverty, disease, squalor, penury and ignorance. Education is the only way of liberating people from problems, be it social, political, economic and so on. The essence of including social studies into the school curriculum is to enhance individual states through effective citizenship and how to ensure individual survival in a society.

\section{The Concept of Social Studies Education}

Ogundare (2002) sees social studies as a school subject who is interested in nurturing into good citizenship with full emphasis on the development of those rational habits of mind and human attitudes that should enable individual learner make informed decision about him or herself and how the problems facing the society can be solved. The primary aim of social studies is to produce a functional, reasonable, rational member of the society who can take necessary action in solving the problems of the society in an attempt to sustain the individual and the society as a whole lyewarun (1989) agreed that if social studies is effectively taught it has the potentials to influence the intellectual, social development and personal growth of the youths.

\section{How Social Studies Education Could Aid the Realization of the Millennium Development Goals in Nigeria}

Millennium Development Goals was specifically designed to eradicate poverty, to foster a national re-orientation, restructuring of values, beliefs, customs, and re-positioning the life style of the developing nations, in which Nigeria is one and how the goal can be use to improve the general standard of living of people in developing nations.

The major focus of the Millennium Development Goals is to eradicated poverty, hungry, poverty is one the age long problems facing humanity along side other closely related problem. Orungbemi (2009) and Osuji (2001) see the effects of poverty as inability to secure balanced feeding, inability to clothe adequately, inability to afford other basic necessities of life, inability to meet social and economic obligation, lack of gainful employment, poverty, connotes physical insecurity, lack of skills, inadequate assets and ignorance, lack of self esteem and powerlessness. Looking at these problems generally, social studies as a discipline is to ensure that it empowers the students to be fully equipped in order to solve various problems facing individuals and the society at large. The focus and the main objective of social studies is to ensure that students have the skills and knowledge to tackle the problems facing the society. The skills to be acquired through social studies is crucial, to make the learner function as an active and competent member of the society.

Ogundare (2004) agreed that the development of critical thinking reflective decision-making and the ability to analyses issues logically and solve problem are stressed in social studies. This is oblivious that functional citizen is the one who can think logically and seriously about his environment and find a lasting solution to the problems on daily basis. Social studies education was specifically, designed and included into the school curriculum in order to free the citizen from the shackles of ignorance, want and poverty in the area of man relations with his varied economic environment, be it industry, agriculture, commerce, political, and also in all cultural situation of diseases, severe poverty and the likes.

The central focus of social studies is man and his environment, the generality of what is happening to man in his 
environment is the major focus of social studies, what man eats, what he wears, what kind of dwelling place he lives and how he makes his environment conducive for himself is the basis for social studies inclusions into the school curriculum.

The core objective of social studies education is creating awareness of opportunities that can be available in ones environment as well as inculcating necessary skills that can enable one to live effectively in ones environment. These skills are to be fully developed through the teaching and learning of social studies. These skills include, skills of listening, speaking, reading, writing, calculation, decision-making as well as those of observation, analysis, synthesis and inference. These skills that learners acquire would enable them to contribute their own quota to the development of their society.

In view of what social studies is all about, the inclusions of social studies into the school curriculum is to justify the fact that it is a subject that can solve the different problems facing the human society. In furtherance to the realization of basic education as advocated in the Millennium Development Goals (MGDs) the role of social studies education needs not to be under estimated. Emunemu (2004), Akinpelu (1992) are of the view that education is the only powerful instrument for social progress, social liberation and it is the greatest power yet known to man for his own improvement and liberation.

Afe (2000) opined that education is seen as tool for the integration of the individual into the society so that he can achieve self realization, develop national consciousness, promote unity and strive for social, political, economic, cultural and technological, scientific advancement to move his/her society forward. In social studies, the learners tend to acquire such knowledge, skills, attitudes and values which may enable a person to function effectively in his or her society. If this assertion is any thing to go by, social studies education becomes a veritable instrument in achieving these goals.

Social studies deals with the teaching of cherished- values, attitudes and norms that are important to national development. The major problems facing the Nigerian society today is misplaced priorities but when right values and attitudes are inculcated in the young ones and they grow up with these values and attitudes, it goes a long way in positively affecting their lives and the society at large. The essence of social studies inclusion into the Nigeria curriculum is to change the perceptions, and re-orientate the thinking faculty of every individual, in term of beliefs and values and how the society can be moved forward. The content of social studies education is flexible in accommodating some issues and problems, so that the issues can be integrated into the social studies curriculum in an attempt to move the society forward; such issues include, human rights, women empowerment, social justice, equity, fairness, AIDs and HIV, Drug abuse, environmental hazard, human trafficking, child abuse, poverty eradication. All these are what the Millennium Development Goals is striving to eradicate, and this can only be possible through the appropriate means of using social studies as a means of eradicating the problems in Nigeria.

Sustainability of the environment is embedded in the Millennium Development Goals; this is as a result of negative effects it has brought on the people especially the less developed countries. Mohammed, (2001) is of the view that environmental problems may arise from poverty and under development as well as through the process of development. Environmental problems are so complex with its multidimensional reality, which cover every domain of our experiencematter, life, and culture. It has resulted in loss of environmental resources, hindered access to safe drinking water, and out break of diseases. Other issues which the Millennium Development Goals is set to address in developing nations include reducing child mortality, improve maternal health and combating communicable diseases such as HIVIAIDs, Malaria, and tuberculosis, and can as well be minimized through adequate knowledge of social studies.

A prominent objective of social studies education is to develop a sympathetic appreciation of the diversity and interdependence of all members of the local community, and the wider national and international community. Social studies recognize the interdependent nature of man and the need for cooperation at the local, national and international level. Concepts like peace, cooperation, integration, international cooperation, togetherness are what is taught in social studies.

However, from what has been stressed so far, it can be ascertained that social studies has a major role to play in the realization of the Millennium Development Goals. Social studies being one of the core subjects at primary and junior secondary levels coupled with its emphasis on the learners, society and the environment can adequately address the issues involved in Millennium Development Goals. If the problems of the society are to be addressed, social studies should be used to catch them young. Incidentally the millennium development goals agenda was never stressed in the curriculum objective of students at all level of education in Nigeria, there bye making the millennium development goals agenda to be difficult to achieve through the educational policy as it was not stressed in the curriculum. 


\section{Conclusion and Recommendation}

The role and contribution of social studies education towards the realization of the Millennium Development Goals have been clearly spelt out in this paper. Despite all, for social studies to efficiently and effectively enhance the realization of these goals the following challenges must be addressed.

However, proper implementation of any curriculum is essentially a function of the quality of the teachers and this lends credence to the need to update this knowledge of teacher who are responsible for social studies curriculum implementation.

There is the need for thorough review of the curriculum to accommodate and sustain the wind of change blowing across the globe, and should indicate a trend towards tapping the Nigeria resources of cherished African traditions and culture.

There should be more use of practical teaching strategies such as role play, inquiry, dramatization, field trips, and simulation to replace the chalk and talk method. This will enable learners to appreciate and internalize these values, attitudes, and skills that would be needed for successful living in the modern world.

The evaluation techniques should be modified from the existing practice of recall type to other techniques like observation, interview, checklist, and other methods that are germane to the development of mind and mankind.

The subject should equally be extended to the senior secondary school level, where every student should realize his potentials as a full and effective citizen. There is need to include the Agenda of the Millennium development Goal to the social studies school curriculum form the elementary classes to the tertiary institutions in Nigeria.

\section{References}

Afe, J.O (2002). Reflection becoming a teacher and the challenges of teacher education, university Benin inaugural lecture series 64.

Ajibola, M.A. (2008). Innovations and Curriculum development for basic education in research Journal of International studies pp 5158.Policy priorities and challenges of practice and implementation.

Awolowo, O. (1981). Path to Nigerian Greatness. Enugu, Fourth Dimension publishing Co. Ltd.

Bamisaiye, R. (1988) "Some philosophical implication of future Direction for African Education" (The Harane Declaration) Journal of Education in Developing Areas. Vols Vi and Vii P.22-34

Cletus, I. Partnership for Sustainable development in small states. 2011

Emunemu, B.O. (2004). The relevance of Nigeria's Universal Basic Education (UBE) programme to National development in Akintayo M.O. Aderinoye, R eds in International toward of Literacy Education, Ibadan, UNESCO chair Publication.

Medunoye. I.(2009)An Evaluation of Public Service Administrators Perception of Millennium Development Goals. Unpublished B.Ed Thesis, Adekunle Ajasin university, Akungba - Akoko.

Moreno, J.M. (2006) The dynamics of curriculum design and development in school knowledge in a comparative and historical perspective. In Benavot, A, Brascarsky, C. (Eds) changing curriculum in primary and secondary education. Hong Kong: Comparative Education Research Center P. 195-209.

Ogundare, S.O. (2002) Fundamental of teaching social studies. Oyo immaculate city publishers.

Orungbemi, O. (2009) Challenges for social studies Edition in Millennium Development Goals (MDGs) in Nigeria.. A journal of Across Africa information Iruces centre Accra Ghana.

Osuji, E.E. (2001). Poverty, Democracy and democratization, Challenges for Political Education. In J.T. Okedara, C.N. Anyanwu, eds, in philosophical Foundations of Adult and Non-formal Education Ibadan, University Press.

Scoullos. M.S. et al (2004) Handbook on methods used in Environment education and education for sustainable development anthens. 
